\title{
Psikonöroimmünoloji ve Multifaktöryel Psikodermatolojik Hastalıklar
}

\section{Psychoneuroimmunology and Multifactorial Psychodermatological Diseases}

\section{Özet}

Psikonöroimmünoloji beyin, nöro-endokrin sistem ve immün sistem arasında nöropeptitler ve hormonlar aracılığıyla kurulan dinamik ilişkileri araştıran yeni bir çalışma disiplinidir. Mental ve psişik faktörlerin immün sistemi ve sonuçta genel sağlığı ne șekilde etkilediğini açıklamayı hedeflemektedir. Deri immün işlevlerin yürütülmesinde kritik bir role sahip bir organdır; iç ve dış stresörlere yanıt veren ve birbiriyle son derece uyumlu çalışan hücre topluluklarını içermektedir. Derideki immün sistem hücrelerinin ve işlevlerinin etkilenmesiyle ortaya çıkan hastalıklarda psişik stres beyin, sinir sistemi ve endokrin sistemi de kapsayan karmaşık olaylar örüntüsü yaratmakta, hastalığın ortaya çıkışı, seyri ve tedaviye yanıtını ödemli ölçüde etkilemektedir. Bu makalede psikojen faktörlerin deriyi nasıl etkilediği ve hangi sistemleri harekete geçirdiği ve psişik stresin etkilediği belli başlı dermatolojik hastalıkların gözden geçirilmesi amaçlanmıştır. (Türkderm 2010; 44 Özel Sayı 1: 10-5)

Anahtar Kelimeler: Psikonöroimmünoloji, psikosomatik hastalıklar, psoriasis, vitiligo, alopesya areata

\section{Summary}

Psychoneuroimmunology is a new discipline which searches dynamic relationship between mind, neuroendocrin system and immune system that is organized via neuropeptides and hormones. It aims to investigate and explain how mental and psychic factors affect immune system and ultimately general health. The skin is an organ which has a critical immune function, and also has cell populations to respond to both intrinsic and extrinsic stressors in a coordinated manner. Psychic stress creates an array of complex events involving the brain, nervous system and immune system in cutaneous diseases in which immun system cells and their functions are affected. It has been aimed to review how psychic stress influences the skin and which systems are driven and also which main dermatologic diseases are involved in this context. (Turkderm 2010; 44 Suppl 1: 10-5)

Key Words: Psychoneuroimmunology, psychosomatic diseases, psoriasis, vitiligo, alopecia areata

\section{Giriş}

Psikolojik ve sosyal faktörler genel olarak hastalıkların ortaya çıkışını, gelişmesini ve iyileşmesini genel olarak psikososyal yapılanma ve sağlıkla ilişkili davranışlar olmak üzere iki şekilde etkiler: Psikososyal yapılanma mental sağlık, kişilik ve duygudurum özellikleri ile sosyal ilişkileri kapsar; kişinin yaşam olayları ve stresörleri algılama ve yorumlama tarzını şekillendirirken stresörlere vereceği yanıtı belirler. Sağlıkla ilgili davranışlar ise egzersiz, beslenme, sigara ve alkol kullanımı gibi davranışları kapsar ve psikososyal etmenlerle birlikte kişinin sağlığını etkiler. Biyopsikososyal modele göre tüm bu etmenler bireyin genetik veya yapısal karakteristikleri ile etkileşime girerek belli hastalıklara zemin hazırlar (diyatez). Buna göre hastalığa uygun genetik predispozisyon stresli olayla karşılaşana dek gizli kalır. Biyopsikososyal model psikosomatik tıbbın temel kavramlarından olup bireyin psikolojisi ile beden sağlığı arasındaki karşılıklı etkileşimi anlamada yarar sağlamaktadır ${ }^{1-4}$.

Psikonöroimmünoloji sinir sistemi, endokrin sistem (hormonlar) ve immünoloji arasındaki karşılıklı ilişkileri ve bu ilişkilerin fiziksel sağlık üzerindeki etkilerini 
araştıran oldukça yeni bir bilim dalıdır ${ }^{4}$ Bu ilişkiler uzun yıllardır bilinmesine karşın ilk kapsamlı tanımı 35 yıl öncesine dayanmaktadır. Bu yeni çalışma alanını tanımlayıcı terim ise ilk kez New York-Rochester Üniversitesi davranışsal ve psikososyal tıp bilimleri başkanı olan Robert Ader tarafından 1975'te kullanılmıştır. Ader kişinin ruh hali, sağlık durumu ve kendini iyileştirme yeteneği arasında bir bağlantı olduğunu ileri sürerek bunu bir deneyle kanıtlamaya çalışmıştır³. O zamandan bu yana yapılan çeşitli çalışmalarda kişinin ruhsal evreni, endokrin ve immün sistem düzenleyicileri arasında merkezi sinir sistemi (MSS) aracılığıyla kurulmuş bir denge olduğu ( homeostazis) gösterilmiştir $^{4-7}$.

Merkezi sinir sistemi tüm vücutta sempatik ve parasempatik sistemleri de içine alan geniş bir iletişim ağına sahiptir. Bu iletişim ağı beynin tüm vücuda " haberci maddeler" adı verilen kimyasallar yoluyla bilgilerin iletilmesini sağlamakta ve vücudun çeşitli çevresel uyarılara gerekli yanıtları oluşturmasını sağlamaktadır. Açıkçası beyin vücudun savunma mekanizmalarını kontrol etmektedir. Başka bir deyişle her düşünce, her duygu veya inanç nörokimyasal bir işlemin oluşmasına zemin hazırlamaktadır.

Nöropeptit (NP) adı verilen bu kimyasal ileticilerin hem MSS hem de immün sistemdeki hücrelerin duvarlarında var olması duygular ve sağlığın birbiriyle son derece yakın bir ilişki içinde olduğunu göstermektedir. Endokrin sistem ise hormon salgılayan organları ile vücudun işlevlerini ve dengesini sağlamaya yardımcıdır. Diğer organların işlevlerini düzenleyen başlıca hormonlar hipofiz, tiroid ve adrenal glandlardan salgılanmaktadır. Haberci maddeler ve alıcılar arasında kurulan bu iletişim ağı organizmayı sürekli olarak dengede tutmaya yönelik bir uyum içinde çalışırken immün sistemin hatasız çalışması gerekmektedir. Araştırmalar duygular, endokrin ve immün sistem düzenleyicileri arasındaki MSS aracılığıyla oluşmuş karmaşık ilişkiler olduğunu göstermiştir. Emosyonel stres karşısında organizma uygun ve istenilen yanıtları oluşturup uyum sürecine girerse denge sağlanmış olur (Cannon ve Selye'nin stres çalışmaları; döğüş ve kaç sendromu) ; ancak stres aşırı ise ya da stres yanıtına karşı aşırı haberci madde ve salgılar oluşursa bir kimyasal karmaşa doğar ve bunun pratik sonucu immün sistemde zayıflama ve artmış hastalık potansiyelidir ${ }^{5,8,9}$.

Bugüne dek 50'den fazla NP tanımlanmıştır ve bunların çoğu davranış ve duygudurum değişiklikleri yaratma etkisine sahiptir. Bunların başlıcaları $P$ maddesi (SP), kalsitonin gen ilişkili peptid (CGRP), vazoaktif intestinal peptid (VIP), nöropeptid $Y$ (NPY), nörokinin A (NKA), nörokinin B (NKB), $\alpha, \gamma$ melanosit stimulan hormon (MSH) gibi propiomelanocortin (POMC) peptidleri $\beta$-endorfin ve somatostatin 'dir. Deri NP'lerin önemli kaynaklarından biridir (Tablo 1). Derideki NP'ler miyelinli $A$ delta fibrilleri ile sensitif ve otonomik lifleri de kapsayan myelinsiz C fibrillerinde depo edilir. Meissner ve Paccini cisimcikleri ile algılanan stres (ağrı, basınç, ısı vb duyusal algılar) bu sinirler kanalıyla serebral korteksteki hipotalamusa iletilir. Bu sistem derinin afferent sinir yolu olarak bilinir. Deride hem afferent sinir yolları hem de kolinerjik ve sempatik sinirler bulunmaktadır. Strese yanıt tüm bu sinir yollarının işleme girmesiyle oluşur. Stresin türü ne olursa olsun nöroendokrin sistem hipotalamik-pitüiter-adrenal (HPA axis) yolla aktifleşir. Önce kortikotropin serbestleştirici hormon (CRH) ve ek olarak vazopresin, daha sonra da adrenokortikotropik hormon (ACTH) salgılanarak dolaşıma geçer. Bu yol klasik geribildirim mekanizmasıdır ve $\mathrm{ACTH}, \mathrm{CRH}$ ve vazopresini baskılayıcıdır. Aynı zamanda otonom sinir sistemi de aktifleşir; spinal gangliyon ve adrenal medulla aracılığıyla noradrenalin ve NP salınımını tetiklenir $\mathbf{r}^{2,5,8,9,10}$ (Resim 1).

Derinin NP kaynakları duyusal sinirlerin dışında keratinositler, melanositler, endotel hücreleri ve immün sisteme ait hücreler tarafından oluşturulur. Monositler ve makrofajlar gibi immün sistem hücreleri derinin yerleşik hücreleri olarak işlev görürken enflamasyon durumlarında göçle gelen hücreler de (lökosit, nötrofil, eozinofil) NP salgılayabilir. Birbiriyle ilişkili tüm olay-

\section{Tablo 1. Derideki nöropeptitler ve işlevleri}

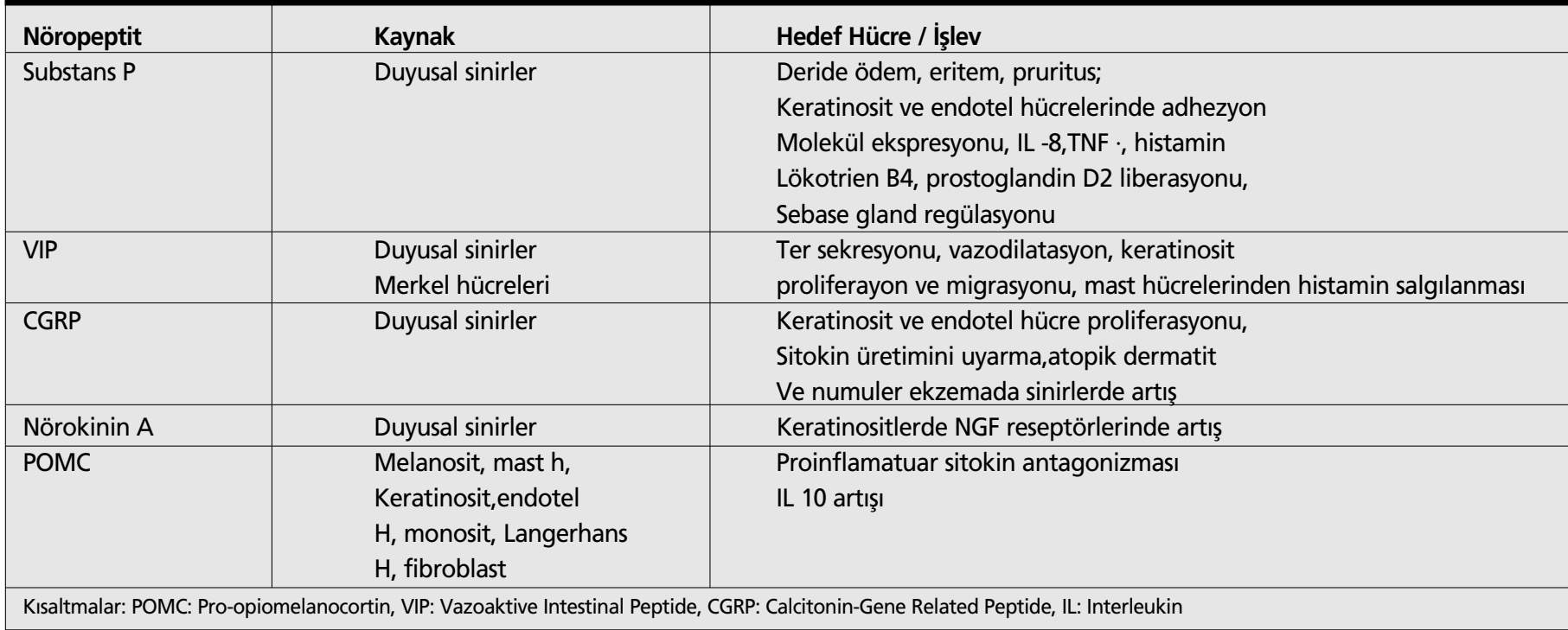


lar ve hücreler arası etkileşimler doku enflamasyonundan (nörojenik enflamasyon) sorumlu başlıca mekanizmayı kurar. Böylece deri iç ve dış kaynaklı stresörlere organize edilmiş ilişkiler toplamıyla yanıt verebilecek çok sayıda hücre topluluğunu barındıran, immünitede önemli bir işlevselliğe sahip bir organdır. Derinin nöroendokrin ve immünolojik sistemlerle ilişkisi nöro -immüno-kutanöz--endokrin sistem yani NiKE olarak adlandırılmaktadır ${ }^{8-10}$.

SP nörojenik yangının temel elemanlarından biridir. Monositler, keratinositler, fibroblastlar,endotel hücreleri ve T hücreleri üzerinde hem aktivite uyarıı hem de hücre çoğalmasını arttırıcı rol oynamaktadır. Derinin mast hücrelerini uyararak histamin ve TNF $\alpha$ salınmasını ve böylece klasik üçlü yanıt denilen ödem, pruritus ve eritem şeklindeki tepkimeyi oluşturur. Ayrıca monositleri ve keratinositleri uyararak proenflamatuar ve kemotaktik interlökinlerden IL-1, IL-6, ve IL-8'in salınımını, dermal fibroblastların migrasyonunu ve proliferasyonunu, endotel hücreleri kanalıyla neovaskülarizasyonu arttırır.

CGRP derideki serbest sinir uçlarında ve vasküler düz kaslarla ilişkili duyu sinirlerinde depolanmıştır. CGRP'nin immün reaktivasyonu keratinositler, Langerhans hücreleri, melanositler, mast hücreleri ve Merkel hücreleri üzerinde ortaya çıkabilmektedir. Emosyonel streste ve psoriatik plaklarda yüksek düzeylerde bulunmuştur. SP'ye benzer şekilde mast hücrelerini uyararak histamin ve TNF $\alpha$ serbestleşnmesini sağlar. Neovaskülarizasyonda uyarııı, vazodilatatör ve endotel hücrelerinden IL-8 salgılatıcı etkilere sahiptir. Polimorf lökositler için kemotaktik, melanosit ve keratinositler için mitojeniktir ${ }^{7-10}$.

VIP dermal damarlar, adneksler ve Merkel hücreleri ile bağlantıda olan sinir lifleri tarafından salgılanır. Keratinositler, ekrin gland epiteli ve immün hücrelerde VIP reseptörleri saptanmıştır. Bu NP de ödem, eritem ve pruritus şeklindeki üçlü yanıtı oluşturabilmektedir. Ayrıca keratinositler için mitojeniktir ve psoriatik plaklarda artmış miktarlarda tespit edilmiştir ${ }^{7-10}$.

Somatostatinin derideki etkileri genel olarak uyarıcıdır. Mast hücrelerinden histamin salınımını ve monositlerin yangı bölgesine göçünü sağlar. $\alpha, \beta$ ve $\gamma \mathrm{MSH}$, ACTH ve endorfin biyoaktif peptidlerdir ve büyük bir prekürsör peptit olan propiomelanokortin'i (POMC) oluştururlar. POMC peptidlerinin kontakt du-

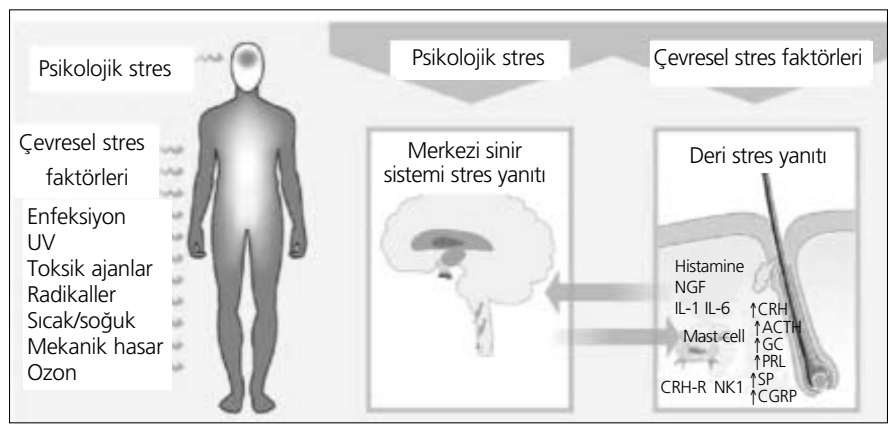

Resim 1. Psikolojik ve çevresel stresörlerin uyarısıyla olulşan beyin-deri ilişkisi. Kısaltmalar: CRH: Corticotropin Releasing Hormone, ACTH: Adrenocorticotropic Hormone, PRL: Prolactine, SP: Substans P, CGRP: Calcitonin-gene-related factor, NGF. Nerve Growth Factor, NK-1: Neurokinin 1, GC: Glucocorticoid,IL: Interleukin (Kaynak 56'dan uyarlanmıştır) yarlık reaksiyonlarını bozduğu gösterilmiştir. ACTH ve $\alpha \mathrm{MSH}$ makrofajların IL-10 salgılamasına neden olarak daha çok inhibitör bir etki yaratır ve immün sistemi düzenleyicidir. ${ }^{7-10}$

Kısaca, tüm NP'ler strese yanıt olarak derideki lokal nöroimmün reaksiyonları düzenlerler. Emosyonel stresle alevlenen bir kısım yangısal deri hastalıklarında altta yatan fizyopatolojik mekanizmalar olaya katılan hücrelerin türüne ve oluşan biyolojik tepkimelere göre çeşitlilik göstermektedir.

\section{Stresle Tetiklenen Multifaktöryel Deri Hastalıkları}

Bu hastalıklar poligenetik bir kalıtımsal zeminde çok sayıdaki iç ve dış etmenlerle ortaya çıkabilen ya da klinik seyirlerinde değişik faktörlerle alevlenen, genellikle kronik ve yineleyici hastalıklar grubudur. Emosyonel stres bu tetikleyici faktörler arasında önemli bir yere sahiptir. Bu nedenle bu grup hastalıklar klasik olarak psikosomatik deri hastalıkları olarak anılırlar ise de otoimmüniter zemin, değişik etiyolojk faktörlerin varlığı ve karmaşık etkileşimler gözardı edilmemelidir. Deri, emosyonel stresten başka organlara göre çok daha fazla etkilenmektedir. Psoriasis, atopik dermatit ve ürtiker gibi bazı deri hastaIıklarında stresörlere uygunsuz glukokortikoid salınımı ile yanıt veren hipotalamik işlev bozukluğunun genetik bir yatkınlık ile ortaya çıktığı ileri sürülmektedir (Diyatez-Stres Modeli ). Buna göre stresle deri hastalığı çıkan ya da alevlenen bir birey kalıtımsal olarak deri hastalığına duyarlıdır ${ }^{10,11}$. Psişik stresle oluşan ya da alevlenen hastalıkların patogenetik açıklamalarını psikonöroimmünolojik mekanizmalarla yapmak mümkündür. Etyopatogenezlerinde NP'lerin önemli rol oynadığı gösterilmiş bulunan ve en fazla çalışılan hastalıklar psoriasis, atopik dermatit, akne vulgaris, ürtiker, vitiligo, alopesi areata, viral deri hastalıklarından herpetik enfeksiyonlar şeklinde sıralanabilir.

Psoriasis

Yıllardır süregelen hekim gözlemleri ve hasta izlenimleri stresli yaşam olayları ve psikososyal etmenlerin hastalığı ortaya çıkarıcı ve/veya alevlendirici rol oynadığını göstermiş ve yakın zamanlara dek yapılan büyük ölçekli çalışmalarla bu gözlemler doğrulanmıştır ${ }^{12-16}$. Stres etkisinin hastalığın ilk ortaya çıkışında $\% 44$, alevlenme dönemlerinde ise $\% 80$ ' e kadar etkili olabildiği gösterilmiş, 40 yaş öncesinde ortaya çıkan erken dönem psoriazislilerde strese duyarlılı̆ın daha fazla olduğu, daha ciddi deri ve eklem tutulumları bildirilmiştir ${ }^{14,15}$.

Psoriasiste interferon $\alpha$ ve TNF $\alpha^{\prime}$ nın etkileri artmış iken Th2 sitokinleri ve IL-4 ile IL-10' un aktiviteleri görece düşüktür. Böylece $\mathrm{T} 1$ lenfositleri esas rolü oynamakta ve hastalık hücresel otoimmüniteden etkileniyor görünmektedir. Bununla birlikte bir kısım araştırıcılar T hücre merkezli immünolojik olayların hastalığın en çarpııı sayılabilecek özelliklerinden Köbner fenomeninin varlığını, simetrik dağılımı, lezyonlarda sinir hücrelerinin ve nöropeptit yoğunluğunun artması gibi özelliklerini tek başına açıklamakta yetersiz kaldığını ileri sürmüşlerdir $^{16-19}$. Psoriatik hastalarda lezyonlu ve lezyonsuz deride patogenetik sürecin erken bir evresinde "nerve growth factor" NGF -Sinir büyüme faktörü 'nün arttığını gösteren bulgular mevcut- 
tur. NGF psikososyal strese yanıt olarak giderek artan miktarlarda üretilir ve mast hücrelerinin migrasyon ve degranülasyonunu sağlayarak nörojenik enflamasyonda anahtar rol oynar. Ayrıca direkt olarak keratinositlere mitojen etki göstererek bu hücrelerin proliferasyonuna yol açar ve T hücre aktivitelerinin de modülasyonunu sağlar. Stres etkisiyle salgılanan NGF ve beraberindeki diğer nöropeptitler (SP, VIP ve CGRP) psoriatik plaklardaki epidermal hiperplazi, dilate damarlar, ödem oluşmasından sorumludur ${ }^{18-21}$.

\section{Atopik Dermatit}

Hastalığın etyolojisi tam olarak bilinmemekte, çeşitli patogenetik açıklamalar olsa bile bunların hiçbiri tek başına yeterli görünmemektedir Patogenezin. halihazırda çok faktörlü olduğu düşünülmektedir.

Stresli yaşam olaylarını takiben ortaya çıkan atopik dermatit (AD) hastaların \%70'inden fazlasında bildirilmiştir ${ }^{22}$. Alevlenmeleri başlatan stres mekanizmaları hastalığın doğal patofizyolojisi kadar karmaşıktır. Bununla birlikte stres glukokortikoidleri bu karmaşık olaylar dizisinde merkezi bir rol üstlenmekte, sitokin profili Th1 hücrelerden Th2 hücrelere kaymaktadır. $A D^{\prime}$ li hastalarda emosyonel stres sağlıklı kontrollerden farklı olarak CD8+ T lenfositlerini, eozinofilleri ve IgE düzeylerini arttırmaktadır ${ }^{23}$. Atopik dermatitin Th2 hastalık mekanizmasının tipik bir örneği olduğu söylenebilir. Atopik bireylerin periferik lökositleri üzerindeki glukokortikoid reseptörleri stres kortizolüne aşırı reaksiyon gösterecek potansiyele sahiptir ve böylece Th2 yönündeki kayış klinikte stres sonucu alevlenen dermatitin akut dönemi ile uyumlu karakteristik bulguları sergiler ${ }^{24}$. Ek olarak stres glukokortikoidleri deri bariyerini de bozarak ev tozları, virüs, bakteri gibi çeşitli allerjenlerin ve patolojik uyarıların deriye girmesine ve dermatiti başlatmasına neden olur. Sempatik kateşolaminler, nöropeptitler (SP,CGRP,VIP) ve nörotrofinlerin bölgesel ve lokal etkilerinin katılımıyla emosyonel strese yanıt olarak gelişen kaşıntı ve akut dermatit tablosu gerçekleşiriri-27.

\section{Alopesi Areata}

Otoimün olduğu düşünülen hastalığın ortaya çıkışı, gelişimi ve tedavisinde psikolojik faktörlerin önemi iyi belgelendirilmiş, nöroendokrin ve immün sistemler arasında önemli etkileşimler olduğu bildirilmiştir. Deneysel çalışmalar akut ve tekrarlayan stres sonucu değişmiş immün yanıta ikincil olarak HPA döngüsünde artmış aktivite ve azalmış $\mathrm{ACTH}$ yanıtı göstermiştir. Başka çalışmalarda ise artmış ACTH ve MSH $\alpha$ düzeyleri saptanırken aktif nörojenik sistem, artmış lokal HPA aks aktivitesi ve TNF $\alpha$ arasında pozitif bir ilişki olduğu gösterilmiştir ${ }^{28}$. Akut emosyonel stres, olasılıkla kıl folikülleri etrafında yerleşmiş olan Tip $2 \beta$ kortikotropin serbestleştirici hormon reseptörlerini aktive ederek yoğun lokal enflamasyona ve saç dökülmesine yol açmaktadır ${ }^{28}$. Ayrıca alopesi areata (AA) alanındaki kıl folikülleri etrafında Substans P (SP)'nin belirgin olarak arttığı ve bunun strese yanıt olarak periferik sinir uçlarından salgılandığı bildirilmektedir ${ }^{28-29}$. Bu moleküler araştırmalar AA'lı hastalarda stres hormonlarının enflamasyon üzerinde etkili olduğunu düşündürürken bazı araştırmacılar stresin o denli etkin ol- madığını ileri sürmektedir. Tan ve ark. 132 AA hastasının sadece \% 9.6'sında stres tanımlarken van der Steen ve ark. AA patogenezinin stresle ilişkili olmadığını düşünmektedir ${ }^{30,31}$.

\section{Vitiligo}

Vitiligoda stresin rolü ile ilgili farklı görüşler vardır. Tıpkı alopesi areatada olduğu gibi vitiligoda da stresin hastalığı belirleyici bir rolü olmadığını gösteren çalışmalar bulunurken az sayıdaki çalışmada vitiligolu hastaların kontrollere göre çok daha fazla sayıda stresli yaşam olayını deneyimledikleri gösterilmiş ve psikolojik stresin başlatıcı etkisi vurgulanmıştır ${ }^{28}$. Stresin vitiligoyu başlatması birkaç mekanizma üzerinden işleyebilir: 1 - immün işlevlerde değişme, 2 - $\beta$-endorfin, $\alpha$-MSH ve metenkefalin gibi opioid peptidlerin üretiminde artma, 3- kateşolaminlerin sentezinde artma, 4- diğer hormon yollarının etkilenmesi. Hastalığın oluşması NP kaynaklı stres, genetik yatkınlık ve karakteristik kişilik yapısı üzerine oturtulmaktadır. Ayrıca hastalığın yol açtığı görüntü anksiyete, özgüven duyusu kaybı ve psikiyatrik morbidite artışına yol açmaktadır ${ }^{32}$. Stresin vitiligoyu nöropeptit mekanizmaları üzerinden tetiklediği netlik kazanırsa sorumlu NP'leri antagonize eden ilaçların kullanımı gündeme gelebilir. Örneğin $\beta$-endorfinlerin kişilik bozuklukları ve kendini yaralama davranışları ile ilgili bozukluklarda artmış olduğu bilinmektedir ve $\beta$-endorfin antagonistleri zaten kullanılmaktadır ${ }^{32}$.

\section{Ürtiker}

Enfeksiyon, alerji, kollajen hastalıklar, endokrin sistem anormallikleri, malinite gibi çoklu etyolojiye sahip bir dermatolojik hastalık olan kronik ürtikerde hastaların büyük bir kısmında neden saptanamaz. Hastalıkta stresin etkilerini gösteren kontrollü çalışma sayısı fazla değildir. Bir çalışmada emosyonel faktörlerin kronik ürtikerli vakaların \%41'inde ve dermografik hastaların da \%42'sinde etkili olduğu gösterilirken kolinerjik ürtikerli hastalarda $\% 80$ oranında atakları tetiklediği tespit edilmiştir ${ }^{33}$.

Bazı kronik idiyopatik hatta fizik ürtikerlerde psikolojik ya da emosyonel stres hipotalamik-vasküler eksen aracılığıyla reaksiyonu başlatıcı etkene kısmen katılabilir ya da reaksiyon başladıktan sonra arttırıcı rol oynayabilir. Emosyonel stres SP, VIP ve CGRP gibi hipotalamik nöropeptitler yoluyla sitokin/histamin dengesini bozar ve deri mast hücrelerini uyararak degranülasyona ve vazoaktif-yangısal maddelerin serbestleşmesine neden olur. Böylece psikolojik faktörler ve stres psikosomatik ürtikerde hem tetikleyici hem de var olan ürtikeri arttırıcı bir rol üstlenir ${ }^{35,36}$. Gerçekte stresin majör rol oynadığı durumlarda gerçek bir alerjiden çok emosyonel ya da psişik bir alerjiden söz etmek mümkündür ${ }^{10}$. Bireysel ve grup terapileri, gevşeme amaçlı stres yönetimi ve hipnoz bu hastalarda yararlı olabilir.

\section{Akne Vulgaris}

Emosyonel stresin, kızgınlık, anksiyete gibi duyguların olumsuz etkisi akneli hastalarda gözlenebilir ataklara ya da alevlenmelere yol açabilir. Emosyonel stres ile aknenin alevlenmesinin altında yatan mekanizma tam olarak bilinmese de bununla ilgili birçok hipotez ileri sürülmüştür. Kuramsal olarak, psikolojik stresle birlikte salgılanan glukokortikoidler ve adrenal androjenler patogenetik zeminde hipotalamik-pitüiter-adrenal aks yoluyla aknenin patogenetik sürecine katkıda bulunmaktadır. 
Bu yolla sebum, substans $P$ gibi nöroaktif nöropeptitler ve humoral yangısal mediyatörler de artarak aknedeki foliküler keratinizasyon ve enflamasyon şeklindeki anahtar patolojiyi desteklemektedir. Periferik sinirlerden salgılanan SP'nin sebase glandların proliferasyonunu stimüle ettiği ve sebase hücrelerde lipit sentezini arttırdığı son zamanlarda gösterilmiştir. SP dışında $\beta$-endorfin, VIP, NPY, CGRP'nin ve opioidlerden MSH $\alpha$ 'nın sebositlerdeki yangısal sitokinleri, hücre çoğalmasını, farklılaşmasını, lipogenez ve androjen metabolizmasını düzenlediği ileri sürülmüştür ${ }^{37-39}$.

1960 'ı yıllardan itibaren strese bağlı klinik alevlenmeler bazı otörler tarafından gözlenmeye başlanmıştır ${ }^{40,41}$. Yakın geçmişte Chiu ve ark Leeds Akne Skalası ve Algılanan Stres Skalasını kullanarak akneli üniversite gençlerinde akne ve stresin sınav zamanlarında belirgin olarak arttırdığını görmüşlerdir ${ }^{40}$. İki yüz on beş öğrenciyi kapsayan bir başka çalışmada tıp öğrencilerinin \%67'sinin akne alevlenmelerinde stresin etkisine inandıkları gösterilmiştir.41 Benzer bir çalışma 33 akne hastasını kapsamış, hastaların \%67'si stresli olayın ortaya çıkması ile aknenin şiddetlenmesi arasında pozitif bir ilişki sunmuştur ${ }^{42}$. Emosyonel stres-akne ilişkisi tedavi odaklı ele alındığında stresin azaltılmasına yönelik girişimlerin genel anlamda akneyi de azaltacağını düşünmek gerekir.

\section{Herpes ve Human Papilloma Virüs Enfeksiyonları}

Yineleyen herpes simplex virüs (HSV) enfeksiyonları, herpes zoster ve human papilloma virüsü (HPV) enfeksiyonlarında emosyonel stresin başlatıcı ve tetikleyici rolü üzerindeki veriler giderek artmaktadı^³-46. Bir çalışmada deneysel oluşturulmuş stres herpes simpleks reaktivasyonuna yol açarken başka bir çalışmada da CD4 helper hücrelerinin stres artışıyla azaldığı ve nükslerin ortaya çıktığı gösterilmiştir. Ayrıca stres nedeniyle serbestleşen immünomodülan sinyal moleküllerinin (kateşolamin, sitokin, glukokortikoid) hücresel immün yanıtı bozarak virüslerin aktivasyonuna katkıda bulunduğu bilinmektedir. Bununla birlikte bazı çalışmalar bu sonuçları desteklememektedir. Bir çalışmada nükslerde hasta kişiliğinin ve stresle başa çıkma mekanizmalarının stresin kendisinden daha önemli olduğu bildirilmiştir. Günlük stresin genital herpes nükslerinde etkisinin olmadığı, gözde yerleşen HSV ataklarının da stresle ilişkili olmadığı gösterilmiştir ${ }^{47-48}$.

\section{Telojen Effluvium ve Androgenetik Alopesi}

Stresin saç dökülmesine olan etkileri uzun süre tartışılmıştır. Akut ya da kronik emosyonel stresin tetikleyici etkilerine değişik araştırıcılar tarafından dikkat çekilmiştir ${ }^{49-50}$. Her ne kadar klinik ve epidemiyolojik çalışmalar emosyonel stresle saç büyüme değişiklikleri arasında kesin bir nedensel bağ kurmakta başarısız olduysa da deneysel hayvan çalışmalarında stresin farelerde saç büyümesi üzerinde önemli ve çoklu etkileri olduğu bulunmuştur. Stres farelerde kıl folikülündeki keratinosit proliferasyonunu engellemekte, erken apopitozla saç folikülünü katajen evreye sokmakta ve mast hücresi aracılıklı nörojenik yangıyı tetiklemektedir. Son bir çalışmada foliküldeki yangısal süreçteki anahtar rolün SP 'ye bağlı olduğu ortaya çıkarılmıştır's1.

Diğer taraftan her iki olayda da görüntünün yarattığı utanç, kızgınlık, acı, depresyon gibi olumsuz duygular nedeniyle kişi- lerin yaşam kalitesinde belirgin düşüş vardır. Stres hem bir başlatıc hem de olayın devamında gelişen bir olumsuz etmendir ve kısır döngü yaratarak saç kaybını arttırıcı rol oynamaktadır. Lichen Ruber Planus: Hastalığın stresle olan ilişkisi uzun yıllardan beri bilinmektedir ${ }^{52}$. Psikolojik faktörlerle adrenerjik sistem aktivasyonu arasında ilişki olduğu gösterilmiştir ${ }^{53}$. NP'lerle hastalık ilişkisini gösteren bazı çalışmalar nörojenik enflamasyonun patogenezdeki rolüne dikkat çekmektedir ${ }^{54}$.

Pruritus/ Prurigo: Özellikle hiçbir somatik nedenin bulunamadığı kronik pruritus'ta (>6 ay) MSS ve deride strese duyarlı karmaşık nöronal bağlantılar ve nörobiyolojik mekanizmalar olduğu ileri sürülmekte, patogenezde NGF, SP and NK1 gibi NP'ler suçlanmaktadır. NGF'nin tıpkı atopik dermatitte olduğu gibi prurigo nodularıste nörohiperplaziye yol açtığı bildirilmektedir. Gelecekte NP reseptörlerini hedef alan terapötik ajanların geliştirilmesi ile kronik kaşıntıların önlenebileceği telkin edilmektedir ${ }^{52,55,56}$.

\section{Kaynaklar}

1. Ader N, Kohen N, Felten D: Psychoneuroimmunology:interactions between the nervous system and the immun system .Lancet 1995;345:99-103.

2. O'Connor MF, Irwin MR: Links between behavioral factors and inflammation. Clin Pharmacol Ther 2010;87:479-82.

3. Fava, GA, Sonino N: The Biopsychosocial Model Thirty Years Later. Psychother Psychosom 2008;77:1-2.

4. Urpe M, Buggiani G, Lotti T: Stress and psychneuroimmunologic factors in dermatology. Dermatol Clin 2005,23:609-17.

5. Miller $A H$, Norin AJ: Neural-immune interactions. Depressive disorders and immunity. Ed. Miller AH. Washington, DC, American Psychiatric Press, Inc, 1989;25-49.

6. Kiecolt-Glaser JK, McGuire L, Robles TF, Glaser R: Psychoneuroimmunology and psychosomatic medicine: back to the future. Psychosom Med 2002;6:15-28.

7. Webber MA: Psychoneuroimmunological outcomes and quality of life. Transfus Apher Sci 2010;42:157-61.

8. Millard L: Psychoneuroimmunology. Psychodermatology: psychologic impact of skin diseases. Ed.Walker C, Papadopoulos L. Cambridge, Cambridge University Press, 2005;15-28.

9. Zane LT: Psychoneuroendocrinimmunodermatology. Psychocutanous medicine. Ed. Koo J, Lee CS. New York-Basel, Marcel Dekker Inc, 2003;65-95.

10. Panconesi E, Hautmann C: Pathophysiology of stress in dermatology. Dermatol Clin 1996;14:319-41.

11. Hart W, Gieler U, Kusnir D, Tausk FA: Clinical management in psychodermatology. Berlin, Springer-Verlag, 2009;196-208.

12. Fortune DG, Richards HL, Griffiths CE, Main CJ: Psychological stress, distress and disability in patients with psoriasis: consensus and variation in the contribution of illness perceptions, coping and alexythymia. Br J Clin Psychol 2002; 2:157-74.

13. Rucoviç I, Bariic Druko V, Vladimira D: Stressful life events as trigger among psoriatics. 12. Congress of the Europen Society for Dermatology and Psychiatry, Wroclaw 2007. Dermatology Cliniczna Suppl : 45

14. Griffiths CE, Richards HL: Psychological influences in psoriasis. Clin Exp Dermatol 2001;26:338-42.

15. Al'Abadie MS, Kent GG, Gawkrodger DJ: The relationship between stress and the onset and exacerbation of psoriasis and other skin conditions. Br J Dermatol 1994;130:199-203.

16. Farber EM, Nickoloff BJ, Recht B, Fraki JE: Stress, symmetry and psoriasis: a T cell disease ? Exp Dermatol 2000;9:359-75.

17. Raychaudhuri SP, Farber EM: Are sensory nerves essential for the development of psoriatric lesions.? J Am Acad Dermatol 1993;28: 488-89. 
18. Raychaudhuri SP, Jiang WY, Farber EM: Psoriartic keratinocytes express high levels of nerve growth factor. Acta Dermato Venereol 1998;78:84-6.

19. Raychaudhuri SP, Jiang WY, Smoller BR, Farber EM: Nerve growth factor and its receptor system in psoriasis Br J Dermatol 2000;143: 198-200.

20. Cirulli F, Alleva E: The NGF saga: from animal models of psychosocial stres to stres related psychopathology. Front Neuroendocrinol 2009;30:379-95.

21. Aloe $E$, Alleva $E$, Fiore $M$ : Stress and nevre growth factor: Findings in animal models and humans. Pharmacol Biochem Behav 2002;73:159-166.

22. Jafferany M: Psychodermatology: a guide to understanding common psychocutaneous disorders. J Clin Psychiatry 2001;9:203-13.

23. Raap U, Kapp A: Neuroimmunologic factors in allergic skin diseases. Curr Opin Allergy Clin Immunol. 2005;5:419-24.

24. Rupprecht M, Rupprecht R, Kornhuber J, Wodarz N, Koch HU, Riederer $\mathrm{P}$, Hornstein P: Elevated glucocorticoid receptor concentrations before and after glucocorticoid therapy in peripheral mononuclear leucocytes of patients with atopic dermatitis. Dermatologica 1991;183:100-5.

25. Kang $H$, Byun DG, Kim JW: Effects of substance $P$ and vasoactive intestinal peptide on interferon gamma and interleukin-4 production in severe atopic dermatitis. Ann Allergy Asthma Immunol 2000;85:225-39.

26. Toyoda M, Nakamura M, Makino T, Hino T, Kagoura M, Morohashi M: Nerve growth factor and substance $P$ are useful plasma markers of disease activity in atopic dermatitis. Br J Dermatol 2002; 147:71-9.

27. Ostlere LS, Cowen T, Rustin MH: Neuropeptides in the skin of patients with atopic dermatitis. Clin Exp Dermatol 1995;20:462-67.

28. Manolache L, Benea V: Stress in patients with alopecia areata and vitiligo. J Eur Acad Dermatol Venereol 2007;21:921-8.

29. Gregoriou S, Papafragkaki D, Kontochristopoulos G, Rallis E, Kalogeromitros D, Rigopoulos D: Cytokines and Other Mediators in Alopecia Areata. Mediators Inflamm 2010;1-5.

30. Tan E, Tay YK, Goh CL, Chin Giam Y: The pattern and profile of alopecia areata in Singapore-a study of 219 Asians. Int J Dermatol 2002;41:748-53.

31. van der Steen P, Boezeman J, Duller P, Happle R. Can alopecia areata be triggered by emotional stress? An uncontrolled evaluation of 178 patients with extensive hair loss. Acta Derm Venereol 1992;72:279-80.

32. Lee E, Koo JMY: Psychiatric issues in vitiligo. Psychocutaneous medicine. Ed. Koo JYM, Lee CS. New York-Basel, Marcel Dekker Inc., 2003;351-63.

33. Sibbald G, Cheema A, Lozinski A, Tarlo S: Chronic urticaria. Evaluation of the role of physical, immunological and other contributory factors. Intern J Dermatol 1991;30:381-6.

34. Newman JC: The neurotransmitter hypothesis of urticaria. Medical Hypothesis 1982;9:617-34.

35. Guillet G, Garcia C, Guillet MH: Urticaire et psychisme: du constat clinique aux neuropeptides. Revue Française d'Allergologie et d'Immunologie Clinique 1998:38:401-4.

36. Singh LK, Pang X, Alexacos N, Letourneau R, Theoharides TC: Acute immobilization stress triggers skin mast cell degranulation via corticotropin releasing hormone, neurotensine and substance P: a link to neurogenic skin disease. Brain, Behaviour and Immunity 1999;13:225-39.
37. Lee WJ, Jung HD, Lee HJ, Kim BS, Lee SJ, Kim do W: Influence of substance-P on cultured sebocytes. Arch Dermatol Res 2008;300:311-6.

38. Cunliffe WJ, Holland DB, Clark SM, Stables GI: Comedogenesis: some aetiological, clinical and therapeutic strategies. Dermatology 2003;206:11.

39. Yosipovitch G, Tang M, Dawn AG, Chen M, Goh CL, Huak Y, Seng LF: Study of psychological stress, sebum production and acne vulgaris in adolescents. Acta Derm Venereol 2007;87:135-9.

40. Chiur A, Chon SY, Kimball AB. The response of skin disease to stress: changes in the severity of acne vulgaris as affected by examination stress. Arch Dermatol 2003;139:897-900.

41. Green J, Sinclair RD: Perceptions of acne vulgaris in final year medical student written examination answers. Australas J Dermatol 2001;42:98-101

42. Polenghi MM, Zizak S, Molinari E: Emotions and acne. Dermatology and Psychosomatics 2002;3:20-5.

43. Buske-Kirschbaum A, Geiben A, Wermke C, Pirke KM, et al: Preliminary evidence for herpes labialis recurrence following experimentally induced disgust. Psychother Psychosom. 2001;70:86-91.

44. Schmidt DD, Schmidt PM, Crabtree BF, Hyun J, Anderson P, Smith C: The temporal relationship of psychosocial stress to cellular immunity and herpes labialis recurrences. Fam Med 1991;23:594-9.

45. Sainz B, Loutsch JM, Marquart ME, Hill JM: Stress-associated immunomodulation and herpes simplex virus infections. Med Hypotheses 2001;56:348-56.

46. Clarke P, Ebel C, Catotti DN, Stewart S: The psychosocial impact of human papillomo-virus infection: implications for health care providers. Int J STD AIDS. 1996;7:197-200.

47. Rand KH, Hoon EF, Massey JK, Johnson JH: Daily stress and recurrence of genital herpes simplex. Arch Intern Med 1990;150:189-93

48. Psychological stress and other potential triggers for recurrences of herpes simplex virus eyeinfections. Herpetic Eye Disease Study Group. Arch Ophthalmol 2000;118:1617-25.

49. Cash TP: The psychology of hair loss and its implications for patient care. Clin Dermatol 2001;19:161-6.

50. Hadshiew IM, Foitzik K, Arck PC, Paus R: Burden of hair loss: stress and the underestimated psychosocial impact of telogen effluvium and androgenetic alopecia. J Invest Dermatol 2004;123:455-7

51. Peters EMJ, Liotiri S, Bodö E, Hagen E, Biro T, Arck PC, Paus R: Probing the effects of stress mediators on the human hair follicle. Am $J$ of Pathol 2007;171:1872-86.

52. Hart W, Gieler U, Kusnir D, Tausk FA: Clinical management in psychodermatology. Berlin, Springer-Verlag 2009;79-121.

53. Puchalski $Z$ (1986) Angststruktur und Parameter von Katecholaminen bei Patienten mit Rosazea, Alopecia areata und Lichen ruber planus. Z Hautkr 61:137-45.

54. Zalewska A, Brzezifska-Blaszczyk E, Omulecki A, Pietrzak A Functional studies of skin mast cells in lichen planus Arch Dermatol Res 1997;289:261-4

55. Stander S, Weishaar E, Luger TA: Neurophysiological and meurochemical basis of modern pruritus treatment. Exp Dermatol 2008; 17:161-9.

56. Arck PC, Slominski A, Theoharides TC, Peters EMJ, Paus R: Neuroimmunology of stress:skin takes center stage. J Invest Dermatol 2006;126:1697-704. 